\title{
PRAGMATIC FUNCTIONS OF INSYA ALLAH IN INDONESIAN SPEECHES
}

\author{
Hendi Pratama \\ English Language and Literature Department \\ Faculty of Language and Arts \\ B3 Building, Universitas Negeri Semarang, 50229, Semarang, Indonesia \\ hendipratama@mail.unnes.ac.id
}

Manuscript received 12 July 2017

Manuscript accepted 17 October 2017

\begin{abstract}
Insya Allah has been part of the Indonesian language and culture for a long time. However, there were very few linguistics studies on the use of Insya Allah. This study aimed to analyse the use of Insya Allah in the Indonesian context using the pragmatic approach. A total of 100 utterances spoken by various speakers at various situations were collected. The study focused on identifying the types of speech acts performed by Insya Allah using Searle's speech act taxonomy (Searle, 1979). At the second stage, the pragmatic functions of Insya Allah were identified using a combination of classifications used by Pishghadam and Kermananshahi (2012), Nazzal (2005), Ibrahim, Shah, and Armia (2013), and Mohamed Ali (2014). The findings showed that Insya Allah was a reliable marker for commissive and expressive speech acts. This study also found two additional pragmatic functions of Insya Allah which have not been identified in previous studies.
\end{abstract}

Keywords: pragmatics, speech act markers, Insya Allah, pragmatic function, sociopragmatics

\section{Introduction}

Insya Allah is an iconic phrase from Arabic that has been adopted into many languages including Indonesian. According to Clift and Helani (2010), Insya Allah literally means "God Willing". In Indonesian, Insya Allah means "If Allah allows" (Tim Pusat Penyusun Kamus, 2005). Around the globe, Insya Allah is an iconic phrase spoken not only by the Muslims, but also by the non-Muslims in predominantly Islamic communities. Murphy (2007, cited in Clift \& Helani, 2010) noted that Insya Allah was spoken by American soldiers who were serving in Islamic states such as Iraq and Afghanistan. Although the semantic meaning of Insya Allah is relatively 
simple, its usage in real life context is quite complex. This study aimed to explore the pragmatic functions of Insya Allah in the Indonesian context which may be different from those identified in previous studies.

Pishghadam and Kermananshahi (2012) mentioned eight main functions of Insya Allah in Persian: (1) to strengthen the speaker's intention, (2) to show a fatalistic intention, (3) to show religious identity, (4) to express hope, (5) to curse, (6) to support someone, (7) to evade, and (8) to postpone things. Pishghadam and Kermananshahi's (2012) study is interesting because it showed how Insya Allah could also be used to curse someone in Persian.

(a) Ishallah beri zire kamion ..... Ishallah tasadof koni bemiri

Insya Allah you would be run over by a truck ... Insya Allah you would have an accident and die.

The use of Insya Allah as a way to curse someone was also identified in Alghazali's (2011) study on Arabic speakers in Iraq.

(b) Insyallahtamuut

I wish you would die

Both Pishghadam and Kermananshahi's (2012) study and Alghazali's (2011) study are unique because the use of Insya Allah to curse is presumably difficult to be obtained in the Indonesian context.

Studies of both semantic and pragmatic analyses of Insya Allah in the Indonesian context are still limited. Susanto (2006) did an analysis of Insya Allah as a feature of code switching. However, Susanto's analysis was only sociolinguistics in nature. The results of Susanto's study showed that the occurrences of code switching using Insya Allah mostly were influenced by metaphorical factors rather than situational factors (Blom \& Gumperz, 1972). In terms of the functions and meanings of Insya Allah, Susanto did not provide an explicit explanation for them. Susanto's argument was supported by Ibrahim, Shah, and Armia (2013) in a study of Insya Allah in the Malaysian context. Ibrahim et al. (2013) also see Insya Allah as a code switching phenomenon rather than a pragmatic one. They consider Insya Allah as one of the markers of a phenomenon called Islamic English. There is a possibility that Islamic English mentioned by Ibrahim et al. (2013) is the same concept dubbed as Islamo English (Mohamed Ali, 2014). Islamo English is a concept where English is used by mixing a language with other Islamic related word roots.

A deeper analysis about Insya Allah functions was done by Nazzal (2005) but it was not in the Indonesian or Malaysian context. Nazzal analysed the pragmatic functions of Insya Allah phrase in the Arabic context of Arabic speakers. Nazzal found that Arabic native speakers used Insya Allah: (1) as a mitigating device for rejection, (2) to implicitly accept a request, and (3) as a mitigating device for future commitment. Generally, Arabic speakers used Insya Allah as a device to solve their doubt of the consequence of their future commitment. From the social point of view, Arabic speakers used Insya Allah to (1) decrease the risk of a speech exchange, (2) maintain harmony, and (3) save participants' face in an exchange.

Pragmatic functions of Insya Allah in Indonesian speeches 
A conversation analysis done by Clift and Helani (2010) showed that Insya Allah is not always used in the context of Al-Quran. It has become a part of both Arabic and non-Arabic daily interactions. Using conversation analysis, Clift and Helani argued that Insya Allah could function as a signal to end a conversation. It could also function as a marker to give hope to future desired outcomes. Insya Allah could also be used to maintain the ongoing topic being discussed. The fourth function was to signal a new topic. At this point, there is only a little difference between the analysis done by Clift and Helani and the one done by Nazzal (2005). Clift and Helani believed that Insya Allah tended to address the future which had a desired outcome while Nazzal stated that Insya Allah was more about speakers' hope to mitigate commitment for an unguaranteed outcome.

As such, studies on Insya Allah have been conducted from various viewpoints including pragmatics, code switching and conversation analysis. In this study, I focus on the pragmatic functions of Insya Allah in the Indonesian context.

The first theory used in this research is the speech theory by Searle (1979). Searle argued that when a speaker produced a speech, it also functioned as an action. When a speaker said that "I name this child, Adam" and the speaker was the legitimate father of the child, the speech uttered could indicate real world situation. That was the beginning of the emergence of speech act theory. Searle's theory is a derivative of Austin's (1975) speech act theory. Austin realized this phenomenon first and Searle formulated that concept even further. Searle revised Austin's speech act classification. He divided speech acts into five categories based on their illocutionary effect intended by the speaker. The classifications of speech acts according to Searle are as follows:

(1) Assertives

(2) Directives

(3) Commisives

(4) Expressives

(5) Declarations
: to tell the truth and the nature of things

: to make someone to do something

: to commit to oneself to do something

: to express one's feeling and attitude

: to change the world reality through speech

In English, Searle (1979) tried to elaborate syntactic analysis which marks each of the speech act. However, the syntactic analyses may not be very useful in analysing speech in Indonesian. From Searle's (1979) example, a speech act can be manifested in more than one syntactic structures, as shown in the following conversation.

(c) Student $X$ : Let's go to the movies tonight.

Student $Y$ : I have to study for an exam.

Adapted from (Searle 1979, p. 43)

Syntactically, Student Y's reaction "I have to study for an exam" is an assertion about his or activities that night. However, in a real life interaction, Student $X$ would understand that Student $Y$ 's utterance is meant to reject $X^{\prime}$ 's proposal. Searle's (1979) syntactic analysis might be irrelevant if it is applied to identify a speech data used in this study. Fortunately, Searle's has provided an 
alternative approach which can be used as an Ockham's Razor for this paper. The razor is called the "felicity conditions". Felicity conditions consist of illocutionary components in each speech act to create an intended perlocution. The following table shows two examples of felicity conditions for two types of speech acts.

Table 1

Felicity conditions adapted from Searle (1979)

\begin{tabular}{ccc}
\hline Felicity conditions & $\begin{array}{c}\text { Directive } \\
\text { (Searle, 1979) }\end{array}$ & $\begin{array}{c}\text { Commissive } \\
\text { (Searle, 1979) }\end{array}$ \\
\hline $\begin{array}{c}\text { Preparatory } \\
\text { Condition }\end{array}$ & H is able to perform A & $\begin{array}{c}\text { S is able to perform A } \\
\text { H wants S to perform A }\end{array}$ \\
\hline Sincerity Condition & S wants H to do A & S intends to do A. \\
\hline $\begin{array}{c}\text { Propositional } \\
\text { content Condition }\end{array}$ & $\begin{array}{c}\text { S predicates a future } \\
\text { act A of H }\end{array}$ & $\begin{array}{c}\text { S predicates a future act } \\
\text { A of S. }\end{array}$ \\
\hline Essential Condition & $\begin{array}{c}\text { Counts as an attempt } \\
\text { to get H to do A }\end{array}$ & $\begin{array}{c}\text { Counts as the } \\
\text { undertaking by S of an } \\
\text { obligation to do A }\end{array}$ \\
\hline
\end{tabular}

The table illustrates that each speech act has to fulfil four illocutionary conditions: (1) preparatory condition, (2) sincerity condition, (3) propositional content condition, and (4) essential condition. The combination of four conditions can be used to differentiate between request and promise by analysing the four felicity conditions. In this research, felicity conditions were utilized to investigate the nature of Insya Allah as a marker to a specific speech act.

\section{Research Method}

Pragmatic analysis has always been a part of linguistic research. In order to present the analysis of Insya Allah pragmatic functions in the Indonesian context, the speech act theory by Searle (1979) was used. In addition, the frameworks from Pishghadam and Kermananshahi (2012), Nazzal (2005), Ibrahim et al. (2013), and Mohamed Ali (2014) were also employed. The use of pragmatic approach to examine data have been conducted by a number of researchers (Argente \& Payrato, 1991; Qadafi \& Wahyudi, 2014). One hundred utterances containing Insya Allah were collected from official and unofficial speeches in Indonesian available on the Internet. The phrase "Insya Allah" was then identified and coded. The speeches were spoken by different types of speakers: the president, mayors, regents, governors, heads of government institutions, heads of private institutions, chief of religious community, parents, and students.

The data were recapitulated in a table and coded. These data were analysed using the the speech act theory by Searle (1979). At the second stage, the data were recapitulated using the classifications of pragmatic functions of Insya Allah generated from the combinations of frameworks by Pishghadam and Kermananshahi (2012), Nazzal (2005), Ibrahim et al. (2013), and Mohamed Ali (2014). The frameworks produced the following taxonomy of the functions of Insya Allah:

Pragmatic functions of Insya Allah in Indonesian speeches 
(1) To strengthen speaker's utterance (a)

(2) To show fatalistic attitude, resigned to fate (a)

(3) To show religious identity (a), (c), and (d)

(4) To wish for good things (a)

(5) To curse someone (a)

(6) To evade future commitment (a) and (b)

(7) To soften negative response (a) and (b)

(8) To accept invitation implicitly (b)

For the sake of efficiency, I omitted the "supportive" and "delaying" functions of Insya Allah formulated by Pishghadam and Kermananshahi (2012) because "supporting" is very similar to expressing good wishes and "delaying" is akin to softening a negative response.

\section{Insya Allah Examined under Searle's Framework of Speech Act}

As an extension from Austin's (1975) speech act theory Searle's (1979) speech act theory also acknowledges that there are three dimensions in a speech act: locution, illocution and perlocution. Locution is the physical form of utterance, spoken or written. Illocution is the message, intention, or meaning of the speakers. Perlocution is reality changing phenomenon affected by the utterances. According to Searle (1979), illocution is the main dimension of speech act which can be analysed using a razor called felicity conditions (see Table 1 ). In order to analyse the corresponding speech act(s) for Insya Allah, felicity conditions were analysed in this study. Felicity conditions consist of four sub-components: (1) preparatory condition, (2) sincerity condition, (3) propositional content condition, and (4) essential condition. By identifying the four subcomponents of an utterance, we can recognize the speech act to which it relates. Based on Searle's (1979) classification, there are five categories of speech acts: (1) directive, (2) commisive, (3) assertive, (4) expressive, and (5) declarative or representative.

Searle (1979) only provides felicity conditions for two categories of speech acts: directive and commissive. For the sake of the study, based on main principles elaborated by Searle (1979), felicity conditions for the other three speech acts are generated here. 
Table 2

Felicity conditions of five types of speech acts

\begin{tabular}{|c|c|c|c|c|c|}
\hline $\begin{array}{l}\text { Felicity } \\
\text { conditions }\end{array}$ & $\begin{array}{c}\text { Directive } \\
\text { (Searle, } \\
\text { 1979) } \\
\end{array}$ & $\begin{array}{c}\text { Commissive } \\
\text { (Searle, } \\
\text { 1979) }\end{array}$ & $\begin{array}{c}\text { Assertive } \\
\text { (Generated) }\end{array}$ & $\begin{array}{c}\text { Expressive } \\
\text { (Generated) }\end{array}$ & $\begin{array}{l}\text { Declarative } \\
\text { (Generated) }\end{array}$ \\
\hline $\begin{array}{l}\text { Preparatory } \\
\text { Condition }\end{array}$ & $\begin{array}{l}\mathrm{H} \text { is able to } \\
\text { perform } \mathrm{A}\end{array}$ & $\begin{array}{c}\mathrm{S} \text { is able to } \\
\text { perform } A \\
\mathrm{H} \text { wants } \mathrm{S} \text { to } \\
\text { perform } \mathrm{A}\end{array}$ & $\begin{array}{c}\text { S knows } \\
\text { something } \\
\text { about } \\
\text { information } \\
\text { A. }\end{array}$ & $\begin{array}{c}\text { S feels } \\
\text { something } \\
\text { about reality } \\
\text { A }\end{array}$ & $\begin{array}{l}\text { S has the } \\
\text { institutional } \\
\text { or cultural } \\
\text { power to } \\
\text { perform A to } \\
\text { come into } \\
\text { effect. }\end{array}$ \\
\hline $\begin{array}{l}\text { Sincerity } \\
\text { Condition }\end{array}$ & $\begin{array}{c}\text { S wants } \mathrm{H} \text { to } \\
\text { do } \mathrm{A}\end{array}$ & $\begin{array}{c}\text { S intends to } \\
\text { do } A \text {. }\end{array}$ & $\begin{array}{l}\text { S wants } \mathrm{H} \text { to } \\
\text { know } \\
\text { something } \\
\text { about } \mathrm{A} \text {. }\end{array}$ & $\begin{array}{l}\text { S wants } \mathrm{H} \text { to } \\
\text { know S's } \\
\text { feeling about } \\
\text { A }\end{array}$ & $\begin{array}{l}\text { S wants to } \\
\text { impose } S^{\prime} s \\
\text { power to } \\
\text { certain } \\
\text { thing(s) or } \\
\text { person(s) }\end{array}$ \\
\hline $\begin{array}{c}\text { Propositional } \\
\text { content } \\
\text { condition }\end{array}$ & $\begin{array}{c}\text { S predicates } \\
\text { a future act } \\
\text { A of } H\end{array}$ & $\begin{array}{c}\text { S predicates } \\
\text { a future act } \\
\text { A of } S .\end{array}$ & $\begin{array}{l}\mathrm{S} \text { wants } \mathrm{H} \text { to } \\
\text { believe } \mathrm{A} \text {. }\end{array}$ & $\begin{array}{c}\text { S predicates } \\
\text { feeling } \\
\text { toward A of } \\
\text { H. }\end{array}$ & $\begin{array}{l}\text { S predicates } \\
\text { changes of } \\
\text { thing(s) or } \\
\text { person(s) }\end{array}$ \\
\hline $\begin{array}{l}\text { Essential } \\
\text { condition }\end{array}$ & $\begin{array}{c}\text { Counts as an } \\
\text { attempt by } S \\
\text { to get } \mathrm{H} \text { to } \\
\text { do } \mathrm{A} .\end{array}$ & $\begin{array}{l}\text { Counts as } \\
\text { the } \\
\text { undertaking } \\
\text { by } S \text { of an } \\
\text { obligation to } \\
\text { do } A \text {. }\end{array}$ & $\begin{array}{l}\text { Attempt to } \\
\text { share } \\
\text { information } \\
\text { A to both S } \\
\text { and H }\end{array}$ & $\begin{array}{l}\text { Attempt to } \\
\text { share feeling } \\
\text { toward } \mathrm{A} \text { by } \\
\text { both } \mathrm{S} \text { and } \mathrm{H} \text {. }\end{array}$ & $\begin{array}{l}\text { Attempt to } \\
\text { change the } \\
\text { reality of } \\
\text { certain } \\
\text { thing(s) or } \\
\text { person(s) }\end{array}$ \\
\hline
\end{tabular}

Using the felicity conditions framework, the utterances collected in the dataset were analysed and tallied. When it came to classifications and identifications of speech acts or any other taxonomy in linguistics, careful measures and considerations must be taken. Some challenges arose in the process. The first one was the possibility of speech acts to overlap. One utterance could be classified into more than one speech act. The second problem was that the position of Insya Allah could be affected by the following and preceding utterances. Thus, this classification was the optimum approximation that could be concluded from utterances containing Insya Allah. In order to increase reliability of data analysis, the analyses from three research assistants were compared, and then discussed so that a consensus could be reached.

\section{Results and Discussion}

The following chart shows the outcome of classification based on the analyses of the speeches. 


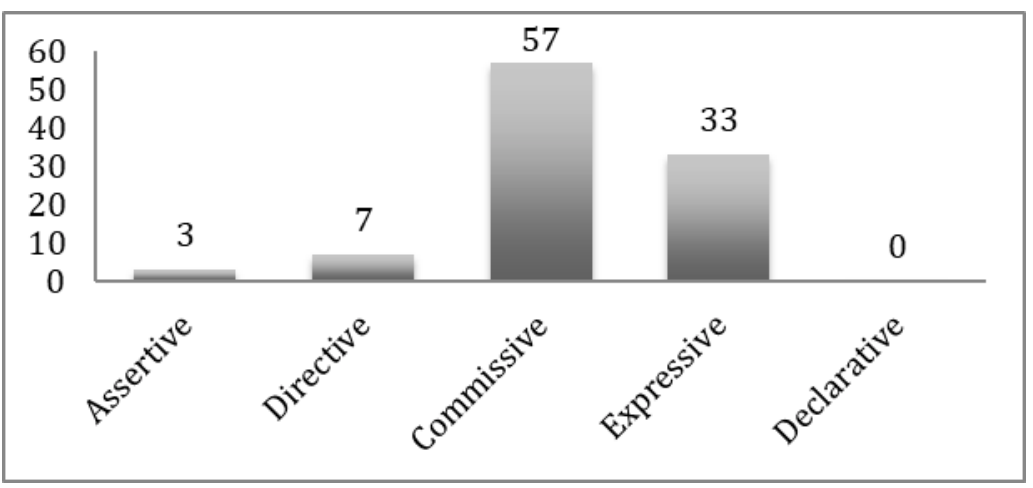

Figure 1. Distribution of Insya Allah based on speech acts classification by Searle (1979)

The felicity conditions of phrase Insya Allah found in the dataset fulfilled the felicity conditions of commissive speech acts very frequently (57\%). Secondly, Insya Allah had quite a high attachment to expressive speech acts (33\%). Thus, commissives and expressives comprised $90 \%$ of the data collected. Directives were found in $7 \%$ of the total occurrences and expressives counted for $3 \%$ of the utterances. In the dataset, Insya Allah never occurred as a declarative marker.

\section{Insya Allah in the Commissive Speech Act}

Insya Allah could be classified as a strong marker for commisive speech acts. The most crucial component of the felicity conditions for the commisive speech act was the speaker's commitment to do something in the future. A simple collocation analysis was conducted and the summarised results are in the following table.

Table 3

Collocation analysis of Insya Allah in 100 Utterances

\begin{tabular}{|c|c|c|c|c|}
\hline \multicolumn{2}{|c|}{ Left Collocation } & \multirow[t]{2}{*}{ Key Phrase } & \multicolumn{2}{|c|}{ Right Collocation } \\
\hline & dan & & akan & \\
\hline 12 & and & \multirow{6}{*}{ Insya Allah } & will & 21 \\
\hline 10 & $\begin{array}{l}\text { yang } \\
\text { which- } \\
\text { relative } \\
\text { pronoun }\end{array}$ & & $\begin{array}{l}\text { kita } \\
\text { we-hearer } \\
\text { included }\end{array}$ & 10 \\
\hline 5 & $\begin{array}{l}\text { ini } \\
\text { this }\end{array}$ & & $\begin{array}{l}\text { penuh } \\
\text { full }\end{array}$ & 5 \\
\hline 4 & $\begin{array}{l}i t u \\
\text { that }\end{array}$ & & $\begin{array}{l}\text { kami } \\
\text { we-hearer } \\
\text { excluded }\end{array}$ & 3 \\
\hline 2 & $\begin{array}{l}\text { kita } \\
\text { we }\end{array}$ & & $\begin{array}{l}\text { pada } \\
\text { on/at }\end{array}$ & 3 \\
\hline 2 & $\begin{array}{l}\text { berjanji } \\
\text { promise- }\end{array}$ & & $\begin{array}{l}\text { Tuhan } \\
\text { God }\end{array}$ & 3 \\
\hline
\end{tabular}




\begin{tabular}{lc}
\hline \multicolumn{2}{c}{ verb } \\
\hline Freq & Freq \\
\hline
\end{tabular}

From the collocation analysis in Table 2, it can be seen that word akan (will/be going to) was the most dominant right collocation. Semantically, the word of akan is related to the future event or commitment. In addition, the word nanti (later) also appeared for many times (seven times) even though it was not classified as collocation. Other collocations such as kita and kami (we/us) did not refer immediately to the speaker. Instinctively, if a speaker commits to something in the future, the most appropriate collocation is ' $I$ '. However in Indonesian, collective pronouns such as kita and kami are considered more appropriate for formal situations to replace the pronoun aku or ' 1 '.

(d) Kami juga menyadari masih banyak program yang belum tuntas kami laksanakan, dan itu semua Insya Allah akan kami tuntaskan dalam masa tiga tahun sisa waktu kepemimpinan kami.

We also realize that many programs have not been completed (by us), and all of those tasks, Insya Allah, we will complete in the next remaining three years of our leadership.

(Datum 85)

In the example, the felicity conditions for the commissive speech act were fulfilled. The speaker thought that he was able to perform the tasks (preparatory condition a). The audience wanted the speaker to perform the tasks (preparatory condition $\mathrm{b}$ ). The speaker intended to complete his program (sincerity condition). The speaker stated that those tasks would be completed in next three years (prepositional content condition). The speaker was obliged to fulfil the promise (essential condition).

\section{Insya Allah in the Expressive Speech Act}

The appearance of Insya Allah as an expressive speech act in the Indonesian context is interesting since the default usage of Insya Allah in the Indonesian language is related to future commitment. Expressives were found many times, hitting 33 times in total. The word penuh (full) most often occurred as right collocation and it was always followed by the word berkah (grace). They formed compound phrase penuh berkah which literally means 'full of grace' or 'full of joy' given by God. In this case, it can be observed that Insya Allah was not used as speaker's evidence of future commitment but it was used to show hope.

(e) Pada kesempatan yang membahagiakan dan Insya Allah penuh berkah ini, saya juga ingin menyampaikan ucapan terima kasih dan penghargaan yang tulus atas pengabdian segenap anggota KORPRI baik yang bertugas di dalam negeri maupun di luar negeri. 
In this very happy occasion and Insya Allah full of joy, I would like to extend my gratitude and sincere appreciation to the devotion of all corps members who are placed inside or outside the country.

(Datum 34)

(f) Selamat bertugas. Insya Allah, Tuhan bersama kita.

Good luck on your duty. Insya Allah, God is with us.

(Datum 36)

(g) Dengan kesabaran Insya Allah kita akan berhasil.

With patience, Insya Allah we will prevail.

(Datum 46)

From the example (e), there was no sign that Insya Allah was used as a future commitment marker in this context. At this point, Insya Allah served as the speaker's psychological expression. All felicity conditions (Searle, 1979) for the expressive speech act had been fulfilled. The speaker felt grateful and happy for the event (preparatory condition). The speaker wanted the audience to recognise the happiness and gratitude of the speaker (sincerity condition). The speaker projected the feelings toward the audience (prepositional content condition). The speaker tried to let the audience feel the shared emotion (essential condition). Utterance ( $f$ ) indicated hope for safety and protection from God and utterance $(\mathrm{g})$ indicated hope for the accomplishment of the task.

\section{Insya Allah in Directive, Assertive and Declarative Speech Acts}

Insya Allah as directive and assertive speech acts will not be discussed in-depth in this research since it appeared as directives only seven times and assertives, three times. With their low frequency, Insya Allah could not be concluded as a marker for directive and assertive speech acts. Nevertheless, it is interesting to note that both directives and assertives, Insya Allah served to mitigate the speakers' proposition and to soften information. The usage of Insya Allah in declarative speech acts could not be found in the dataset. This phenomenon is most probably due to the existing phrase of Bismillah. In most inaugurations in Indonesia, declarative speech acts use Bismillah which literally means 'in the name of God' instead of Insya Allah.

\section{The Pragmatic Functions of Insya Allah}

Tallying technique could not be used in this section since one utterance of Insya Allah can have more than one function. In other words, the nature of pragmatic functions of Insya Allah are composites. Please take a look at the following datum.

(h) Kita mempunyai keyakinan bahwa segala sesuatu perbuatan yang kita lakukan dengan niat dan tulus tidak terkecuali dalam memberikan pelayanan kepada masyarakat, Insya Allah akan membuahkan kebaikankebaikan yang kelakakan dicatat sebagai nilai ibadah. 
We believe that every single act we do with unconditional will and sincerity to serve the society, Insya Allah will result in goodness to be recorded as our deeds (by God).

(Datum 23)

From the example (h), the utterance containing Insya Allah had more than one functions. The first function was to strengthen the speaker's utterance. The second function was to submit to fate. The third function was to show religious identity by using Insya Allah combined with word ibadah which means 'good deeds recorded by God'. The last function was to wish for good things. Considering the composite trends in Insya Allah utterance, I decided not to impose frequency recapitulation in this section.

The next finding is related to the characteristic of this research's data. Since this study focused only on speeches, there was no interaction between speaker and hearer. Thus, the functions of evading a future commitment, softening a negative response, and accepting an invitation implicitly, could not be found and clarified using the dataset.

Apart from previous findings stating that Insya Allah could be used to swear and to curse (Alghazali, 2011), none of the data in this study could support that. It can be observed that in the Indonesian context, speakers in the study tended to use Insya Allah with positive connotation in speeches.

Strengthening speaker's utterance and wishing for good things (Pishghadam \& Kermananshahi, 2012) were two pragmatic functions of Insya Allah, which often co-emerged. The possible tendency was that when a speaker wanted to strengthen or heighten the illocutionary effect of his/her speech using Insya Allah, he/she also wanted to wish for good outcome in the future.

(i) Dengan berbagai upaya itu, Insya Allah, kita akan memiliki tatanan mitigasi dampak secara nasional yang lebih kokoh dan lebih baik di masa depan.

With all the efforts, Insya Allah, we will have a mitigation governance system nationally which is not only stronger but also better in the future.

(Datum 30)

In speech excerpt (i), the speaker used Insya Allah to highlight the sense of positive outcome to the audience. It can be safely said those two functions, strengthening speaker's utterance and wishing for good things, were complementing each other most of the time.

Showing fatalistic attitude and showing religious identity also often cooccurred. Showing fatalistic attitude could be identified by any words indicating the surrender of the speakers to God. Religious identity could be characterized by words or phrases, which indicated specific terms used by the Muslim community such as ibadah, walimatul urus, I and istigomah.

(j) Semoga upaya kita dalam membangun dan menegakkan kewibawaan Indonesia yang kita cintai bersama ini, senantiasa mendapatkan ridhlo-Nya dan menjadi catatan amal ibadah kita, Insya Allah. 
Hopefully, all our efforts in building and erecting the greatness of our beloved Indonesia will get ridho from God and becomes our ibadah, Insya Allah.

(Datum 21)

Based on example (j), Islamic identity could be confirmed using Insya Allah accompanied with other Islamic terms such as ridho (blessing) and ibadah (worship). As a country with the largest Muslim population in the world, it seems natural that highlighting Islamic identity is beneficial for speakers for in-group bounding. At the same time, the speaker shall show his/her submission to God for the success or failure of the efforts he/she has made. This finding supports previous study by Pishghadam and Kermananshahi (2012) on showing fatalistic attitude and study by Ibrahim et al. (2013) on how language can be used to show Islamic identity.

There were some functions identified in this research, which did not fit into the provided categories. Additional functions were most visible when Insya Allah was used to indicate a definite plan scheduled in the future. This function appeared several times in different speeches.

(k) Pengajian rutin tiap malam jum'at depan Insya Allah akan kita laksanakan di rumah Ibu Ifa blok C3 nomor 19.

The weekly meeting of the next Thursday night, Insya Allah, will be held in Mrs.Ifa's House at Block C3 number 19.

(Datum 8)

(I) Insya Allah 9 Desember 2015 nanti kita menyelenggarakan Pilkada serentak di 21 Kabupaten/Kota

Insya Allah, on 9 December 2015 we will have our regional election simultaneously in 21 regencies/cities.

(Datum 12)

Looking at the data in (k) and (I), the speakers used Insya Allah and at the same time they mentioned the exact date of the pre-planned events. The use of Insya Allah in this case was not related to religious identity or submission to fate. Insya Allah in this case was also not a statement of strengthening nor highlighting hope. Therefore, I propose that the function 'to indicate scheduled future plan' to be added to the list of the existing functions. This type of function occurred quite frequently in the speeches. In the dataset, this function appeared 14 times.

The last function of Insya Allah, which could not be found in the previous studies was to convey humour. However, the occurrence of this function was rare.

(m) Jika Bapak Ibu pulang sebelum makan tidak akan didoakan oleh ustads KH.A.Yani Hamid (Ketua MUI Kab. Musi Rawas) untuk menyusul kami naik haji tahun mendatang, sebaliknya bila bapak-ibu makan dulu baru pulang Insya Allah akan didoakan untuk naik haji ditahun-tahun mendatang, bagi yang pernah berhaji akan pergi lagi berkali-kali. 
If you go home before trying any meals, you won't get any blessing from KH. A. Yani Hamid (Head of MUI Musi Rawas) to go on Hajj like us in the coming years. On the other hand, if you try the meal first and then go home, Insya Allah, he will pray for you to go for Hajj in the coming years; for the ones who have been on Hajj will get the opportunity to go on Hajj again several times.

(Datum 83)

\section{Conclusion}

There are two research questions in this study. First, what is the nature of Insya Allah as a speech act? Secondly, what are the pragmatic functions of Insya Allah based on the combined taxonomy provided by previous studies?

On the first question, based on Searle's taxonomy, the study has shown that most of the time Insya Allah indicated commisive speech acts (57\%). In those instances, Insya Allah was related to the speakers' commitment to future actions or events. In $33 \%$ of the occurrences, Insya Allah was used as expressive speech acts. Here, Insya Allah was used as a psychological and/or an emotional expression with no connection to future affairs. There were very few directives and assertives in the dataset and no declarative was found in the dataset.

The second question is related to the pragmatic functions of Insya Allah. The study revealed that in Indonesian speeches, Insya Allah functioned to strengthen the speaker's utterance, to wish for a good outcome, to show a fatalistic attitude and to show religious identity. There were three functions from previous studies which were not found in this study: (1) to evade from future commitment, (2) to soften negative response and (3) to accept invitation implicitly. The absence of these three functions could be due to the restricted nature of the data source. Cursing using Insya Allah (Alghazali, 2011) was also not found in the dataset. However, two functions of Insya Allah which were not reported in previous studies were identified in the findings of this research: (1) to indicate scheduled future plans, and (2) to convey humour.

The main shortcoming of this study is that the source of the data was restricted to speeches. The monological nature of the data source could be the reason why some pragmatic functions of Insya Allah identified in previous studies were not found in the present study. To address this shortcoming, future research on the use of Insya Allah in other situations could be carried out.

\section{References}

Alghazali, T. (2011). Insha'Allah (God's willing) and its functions in Arabic. Retrieved from

https://www.academia.edu/12488637/Insha_Allah_God_s_Willing_and_its_F unctions_in_Arabic

Argente, J. A., \& Payrato, L. (1991). Towards a pragmatic approach to the study of languages in contact. Pragmatics, 1(4), 465-480. 
Austin, J. L. (1975). How to do things with words. Oxford, UK: Oxford University Press.

Blom, J. P., \& Gumperz, J. J. (1972). Social meaning in linguistic structure: Code switching in Norway. In J. J. Gumperz, \& D. Hymes (Eds.), Directions in Sociolinguistics (pp. 407-434). New York,NY: Holt, Rinehart and Winton.

Clift, R., \& Helani, F. (2010). Inshallah: Religious invocations in Arabic topic transition. Language in Society, 39(03), 357-382.

Ibrahim, E. H. E., Shah, M. I. A., \& Armia, N. T. (2013). Code-switching in English as a foreign language classroom: Teachers' attitudes. English Language Teaching, 6(7), 139.

Mohamed Ali, H. M. (2014). Islamo-English: A variety of English for the ummah. Research Journal of English Language and Literature, 2(3), 68-75.

Nazzal, A. R. (2005). The pragmatic functions of the recitation of Qur'anic verses by Muslims in their oral genre: The case of Insha' Allah, God's willing. Pragmatics, 15(2), 251-273.

Pishghadam, R., \& Kermanshahi, P. N. (2012). Insha'Allah (God's willing) and its functions in Persian. Studies in Literature and Language, 4(1), 6-11.

Qadafi, A. M., \& Wahyudi, R. (2014). Advertising language: A pragmatic approach to cigarette advertisements in Indonesia. Issues in Language Studies, 3(1), 1-14.

Searle, J. R. (1979). Expression and meaning: Studies in the theory of speech acts. Cambridge,UK: Cambridge University Press.

Susanto, D. (2006,February). Codeswitching in Islamic religious discourse: The role of Insha' Allah. Paper presented at Second Annual Rhizomes: Re-visioning Boundaries Conference of The School of Languages and Comparative Cultural Studies, Brisbane, Australia. Retrieved from https://espace.library.uq.edu.au/data/UQ_7714/ds_rhiz.pdf

Tim Penyusun Pusat Kamus. (2005). Kamus besar bahasa Indonesia [Main dictionary of Indonesian language]. Jakarta, Indonesia: Balai Pustaka. 